UDC 613.955: 613.861: 613.65.027-053.5

DOI: $10.21668 /$ health.risk/2018.2.07.eng

\title{
PECULIARITIES OF NEURO-PSYCHIC STATE AND LIFE QUALITY OF CHILDREN AND TEENAGERS FORMED UNDER INFLUENCE EXERTED BY RISK FACTORS EXISTING IN EDUCATIONAL ENVIRONMENT
}

\author{
A.G. Setko, E.A. Terekhova, A.V. Tyurin, M.M. Mokeeva \\ Orenburg State Medical University, 6 Sovetskaya Str., Orenburg, 460000, Russian Federation
}

Today education is being modernized in the RF and it involves active development of innovative educational establishments, particularly, those where students stay round-the-clock. Intra-school environment in such establishments has its peculiarities and there are several factors in the educational process there which influence a child's body thus deteriorating his or her physical and mental health. To make educational processes efficient in such establishments, it is necessary to pay close attention to children's neuro-psychic state and quality of their life. Our research goal was to assess students' neuro-psychic state and quality of their life in an educational establishment where they stayed round-the-clock. We performed this assessment via questioning with standard questionnaires. As a result, we revealed that such adverse factors in the intra-school environment as non-rational organization of the educational process and daily regimen led to poorer neuro-psychic state and lower quality of children's life. It became obvious through an increase in number of students with higher anxiety level, from $16 \%$ in the fifth grade to $19 \%$ in the tenth grade. Both physical and mental components of life quality also deteriorated. We revealed that anxiety level and life quality parameters depended on non-rational organization of the educational process and daily regimen.

The existing situation calls for working out and implementation of modern preventive healthpreserving activities and active medical support provided for the educational process; these activities should be aimed at lowering risks caused by negative influence exerted by intra-school environment factors on students' neuro-psychic state and quality of their life.

Key words: neuro-psychic state, life quality, educational process, children, teenagers, risk factor, educational environment.

The system of school education in the RF has been undergoing substantial reforms over the recent years. These reforms, in particular, involve creation of occupational training for senior school students, and it results in greater education loads. So, it is necessary to explore issues related to health preservation in case of children and teenagers who attend new innovative educational establishments where intensive training technologies are implemented, including those schools where students stay round-the-clock $[1,2]$. Educational processes in such establishments have their peculiarities which are determined by round-the-clock influence exerted on a child's body by a set of intra-school factors and intense educational loads; this influ-

(C) Setko A.G., Terekhova E.A., Tyurin A.V., Mokeeva M.M., 2018

Andrey G. Setko - Doctor of Medical Sciences, Professor, head of Department for Children's and Teenagers' Hygiene and Nutrition and Occupational Hygiene (e-mail: a isetko@mail.ru; tel.: +7 (3532) 50-06-06 (ext. 401)).

Elena A. Terekhova - Assistant at Department for Children's and Teenagers' Hygiene and Nutrition and Occupational Hygiene (e-mail: lenochka0419@mail.ru; tel.: +7 (3532) 50-06-06 (ext. 402)).

Alexander V. Tyurin - Candidate of Medical Sciences, Associate Professor at Department for Disastrous Accidents Medicine (e-mail: K GDiP@orgma.ru; тел.: +7 (3532) 50-06-06 (ext. 401)).

Marina M. Mokeeva - Candidate of Medical Sciences, Associate Professor at Department for Children's and Teenagers' Hygiene and Nutrition and Occupational Hygiene (e-mail: K_GDiP@orgma.ru; tel.: +7 (3532) 50-06-06 (ext. 402)). 
ence leads to disorders both in physical and mental health of a student [3-5].

Successful adaptation of children and teenagers during their studies in modern educational establishments depends on a great number of life activity factors which form students' biological and psycho-social state [1, 4-11]. Round-the-clock complex exposure of students' bodies to intra-school factors involves greater educational loads and greater volumes of information which students have to obtain and process. At the same time, students permanently stay in a closed establishment; they are educated under a strict daily regimen and are constantly under their tutors' control; an amount of time they can spend in privacy is minimal, and they socialize only with their classmates [4]. All this makes them fundamentally different from other children and teenagers of the same age who attend other educational establishments with a different structure of social and mental adaptation. Some data reveal that this structure is characterized with significant level of deadaptation in educational and behavioral spheres and emotional illbeing $[12,13]$.

Given all the above-mentioned, it is necessary to explore neuro-psychic state and life quality of students as well as to detect factors which deteriorate them.

Our research goal was to assess neuro-psychic state and life quality of students who attended an educational establishment with round-the clock staying.

Data and methods. We performed our research on 536 students who attended an innovative comprehensive educational establishment with round-the-clock staying in Orenburg; students were examined in dynamics from the 5 th to the 10th grade and their age was from 12 to 17.

We explored how educational processes were organized in the establishment; our research included determining daily and weekly educational loads, how these loads were distributed over a day and a week, and how school subjects were assigned depending on their complexity over a day and a week taking into account dynamics of students' physiological working capacity. Cadets' daily regimen was assessed on the basis of the daily routine fixed in the establishment; we paid attention to six basic components of any daily regimen, their presence and duration, and their conformity to the existing hygienic requirements. The obtained data were then compared with the Hygienic Requirements 2.4.2.2821-10 "Sanitary-epidemiologic requirements to conditions and organization of an educational process in comprehensive secondary schools"1.

Children's neuro-psychic state was assessed via questioning. Personal traits were examined by determining an anxiety level and negative emotional experience both in everyday life and during classes. We applied Ch.D. Spielberger's questionnaire, modified by Andreeva (1988). Level of aggression was determined as per BussDurkey Inventory (20002), and character traits, as per A.E. Lichko's questionnaire

\footnotetext{
${ }^{1}$ SanPiN 2.4.2.2821-10. Sanitarno-epidemiologicheskie trebovaniya k usloviyam i organizatsii obucheniya v obshcheobrazovatel'nykh uchrezhdeniyakh (s izmeneniyami na 24 noyabrya 2015 goda): Postanovlenie glavnogo gosudarstvennogo sanitarnogo vracha RF № 189 ot 29.12.2010 g. [HR 2.4.2.2821-10. Sanitary-epidemiologic requirements to conditions and organization of an educational process in comprehensive secondary schools (with the latest alterations adopted on November 24, 2015): The Order by the RF Chief Sanitary Inspector dated December 29, 2010 N 189].Available at: http://docs.cntd.ru/document/902256369 (18.02.2018) (in Russian).

${ }^{2}$ Baranov A.A., Kuchma V.R., Sukhareva L.M. [et al]. Otsenka nervno-psikhicheskogo zdorov'ya i psikhofiziologicheskogo statusa detei i podrostkov pri profilakticheskikh meditsinskikh osmotrakh: posobie dlya vrachei [Assessment of neuro-psychic health and psychophysiological state of children and teenagers during prevention medical check-ups: A manual for phvsician1.Moscow. 2005. 137 p. (in Russian).
} 
(1995) with character accentuation types being determined as well ${ }^{2}$.

Life quality was assessed via questioning with MOS-SF-36 questionnaire (J.E. Ware, 1992) modified by the International Center for Life Quality Exploration (Saint Petersburg, 1998). The assessment was performed as per 8 scales, 4 of them characterizing a physical component, and other 4, a mental one [14].

We applied Person's technique (B.A. Rosner, 1982) to reveal cause-andeffect relationships between risk factors existing in the educational environment in a military school, parameters of neuropsychic state, and students' life quality. All the obtained data were statistically processed with the following software: "Microsoft Office Excel" 2007 and "Statistica" universal statistic package, version 10.0 for Windows.

Results and discussion. Our assessment of the educational process revealed that it was organized in a nonrational way. There were apparent irregularities in classes scheduling for a day and for a week as difficulty of various subjects and physiological dynamics of students' working capacity were not taken into account. We detected that students attending the 5th, 6th, and the 8th grade had to bear high educational loads at the beginning of the week (50-59 scores); students attending the 9th and the 10th grade, at the end of it (46-49 scores); it didn't correspond to periods when students just started to adjust to work, and when their working capacity decreased. Educational loads in the middle of the week were low (26-36 scores) in the 5th, 7th, 8th, and 9th grades, and it didn't correspond to a period of high and stable working capacity either. We detected dual classes in the same subject, absence of rotation between humanitarian classes and classes in mathematics and natural sciences, as well as rotation between "dynamic" classes (sports, technology, music, and art) and "static" ones (basic subjects).

Students' daily regimen also deviated from the fixed standards. Thus, a period of time assigned for doing homework was shorter than the standard by $24.0 \%$ for the 5th grade students; by $36.7 \%$, for the 6-7th grade students; by $10.0 \%$, for the 8-9th grade students; by $32.5 \%$, for the 10th grade students. Duration of time spent walking outdoors was shorter than the standard by $73.6 \%$ for the 5 th grade students; by $58.3 \%$, for the 6-9th grade students; by $50.0 \%$, for the 10 th grade students. Night sleep was $10.0 \%$ shorted than the standard for the 5th grade students. A period of time assigned for personal hygiene, morning exercises, and breakfast, was $35.0 \%$ longer than the standard for the 6-9th grade students; $68.7 \%$ longer, for the 10th grade students.

Our assessment of anxiety levels revealed that high anxiety levels during classes were detected in $1.0 \%$ of the 9 th grade students, but in $23.0 \%$ of the 8 th grade students; high anxiety levels in everyday life were detected in $7.0 \%$ of the 9th grade students, and in $23.0 \%$ of the 5 th grade students (Table 1).

We assessed a number of students with high anxiety levels in dynamics and detected that there was an increase in number of students who had high anxiety levels during classes, from $16.0 \%$ in the 5 th grade to $19.0 \%$ in the 10 th grade. But as for anxiety in everyday life, a number of students with it fell from $23.0 \%$ in the 5 th grade to $9.0 \%$ in the 10 th grade. These data prove there are changes in students' emotional state which are probably related to an inadequate reaction of a body to educational loads. 
Table 1

Distribution of students depending on anxiety levels in everyday life and during classes

$(\%)$

\begin{tabular}{|c|c|c|c|c|c|c|c|c|c|c|c|c|}
\hline \multirow{3}{*}{ Anxiety levels } & \multicolumn{12}{|c|}{ Classes } \\
\hline & \multicolumn{2}{|c|}{5} & \multicolumn{2}{|c|}{6} & \multicolumn{2}{|c|}{7} & \multicolumn{2}{|c|}{8} & \multicolumn{2}{|c|}{9} & \multicolumn{2}{|c|}{10} \\
\hline & 1 & 2 & 1 & 2 & 1 & 2 & 1 & 2 & 1 & 2 & 1 & 2 \\
\hline Low & 11,5 & 17,3 & 50,5 & 35,5 & 54,8 & 47,3 & 27,1 & 33,3 & 47,4 & 42,1 & 4,2 & 4,2 \\
\hline Average & 65,4 & 66,3 & 36,6 & 51,6 & 33,3 & 43,0 & 50,0 & 43,8 & 46,1 & 56,6 & 86,5 & 77,1 \\
\hline High & 23,1 & 16,4 & 12,9 & 12,9 & 11,9 & 8,6 & 21,9 & 22,9 & 6,5 & 1,3 & 9,3 & 18,7 \\
\hline
\end{tabular}

Note: 1 is in everyday life; 2 is during classes

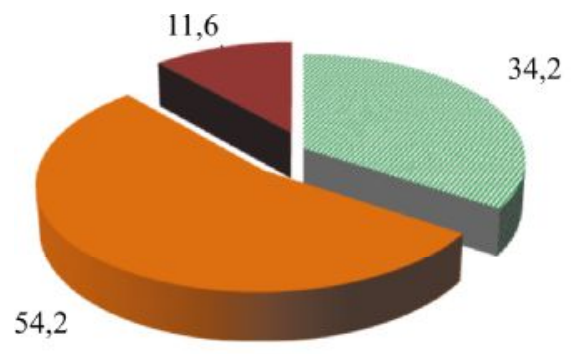

$a$

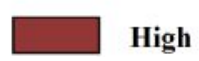

34,2

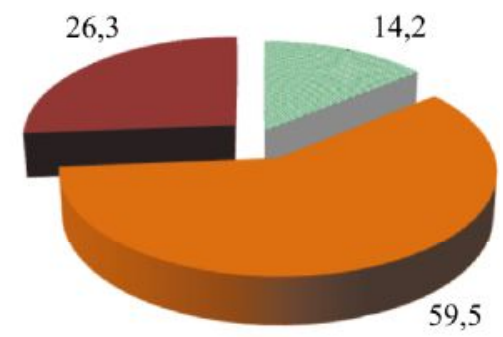

$b$

Average

Low

Figure 1. Evidence of negative emotional strain (stress):

$a$ - in everyday life; $b$ - during classes

High anxiety levels lead to stress occurrence; therefore, $12.0 \%$ and $26.0 \%$ students were under high stress in everyday life and during classes accordingly (Figure $1)$.

We examined learning in dynamics and revealed the greatest number of students under high stress level in everyday life in the 8th grade (43\%); under high stress level during classes, in the 6th grade (18.0\%) (Table 2).
Stress occurrence, in its turn, led to emergence of aggression in students. We revealed that aggression signs were quite adequate in $50.0 \%$ students; $40.0 \%$ had them but tried to suppress their aggression; and only $2.0 \%$ behaved truly aggressively (Figure 2).

Depending on time spent in the educational establishment, a number of students with adequate signs of aggression went up to $58.8 \%$; levels of aggression remained approximately the same (Table 3 ).

Table 2

Distribution of students depending on the level of negative psychoemotional strain (stress), \%

\begin{tabular}{|l|c|c|c|c|c|c|c|c|}
\hline \multirow{2}{*}{$\begin{array}{c}\text { Level of negative psychoemotional } \\
\text { strain (stress) }\end{array}$} & \multicolumn{9}{|c|}{ Classes } \\
\cline { 2 - 10 } & \multicolumn{2}{|c|}{6} & \multicolumn{2}{|c|}{7} & \multicolumn{2}{c|}{8} & \multicolumn{2}{c|}{9} \\
\cline { 2 - 10 } & 1 & 2 & 1 & 2 & 1 & 2 & 1 & 2 \\
\hline Low & 11,8 & 19,3 & 12,5 & 22,4 & 12,8 & 49,5 & 28,9 & 39,5 \\
\hline Average & 46,2 & 62,4 & 31,2 & 63,2 & 20,0 & 30,9 & 36,8 & 46,1 \\
\hline High & 17,3 & 18,3 & 15,0 & 13,2 & 42,5 & 15,5 & 7,9 & 7,9 \\
\hline
\end{tabular}

Note: 1 is in everyday life, 2 is during classes 


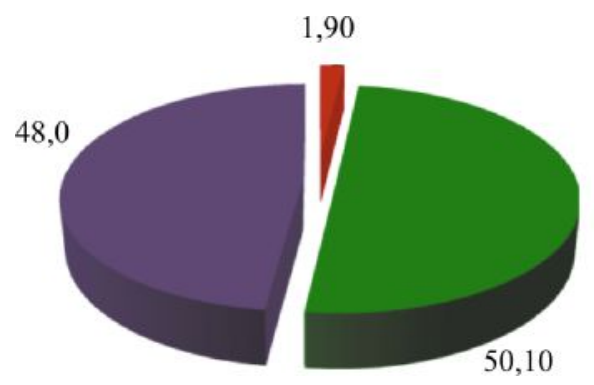

aggressive behavior

adeguate signs of aggression

aggression is suppressed

Figure 2. Signs of negative emotional strain (aggression).

As we assessed character accentuation types in students from the 6th - 9th grades, we detected that most of them had a mixed type of character accentuation (from $27.2 \%$ in the 8 th grade to $38.7 \%$ in the 9 th grade) (Table 4).

A character accentuation type which could not be diagnosed accounted for a rather high share, $10.7 \%$ in the 9th grade, and up to $25.0 \%$ in the 7 th grade. About $2.0 \%$ students in the 7 th grade and up to $12.0 \%$ students in the 9th grade had hyperthymic character accentuation which is characterized with great willingness to act but also with a tendency to do too much at once and to abandon tasks without completing them. It is important to note that about $6.4 \%$ students in the 6 th grade and up to $25.0 \%$ students in the 7 th grade had demonstrative character accentuation; a person with such accentuation type behaves demonstratively, is emotional and vivid, makes contacts easily, strives for leadership, is eager to be recognized and to constantly attract everybody's attention. And here we should also note that $1.9 \%$ students in the 8 th grade and up to $12.0 \%$ in the 7th grade had anxious-pedantic accentuation type, or, in other words, were indecisive, prone to thinking and selfanalysis, and susceptible to obsessive fears and thoughts. Other types of character accentuation were rather rare.
Table 3

Distribution of students depending on levels of aggression (\%)

\begin{tabular}{|l|c|c|c|c|}
\hline \multirow{2}{*}{ Level of aggression } & \multicolumn{4}{|c|}{ Classes } \\
\cline { 2 - 5 } & 6 & 7 & 8 & 9 \\
\hline Aggressive behavior is natural & 1,8 & 2,6 & 1,0 & 2,4 \\
\hline $\begin{array}{l}\text { An examined person tends to } \\
\text { demonstrate adequate signs of } \\
\text { aggression in certain situations }\end{array}$ & 49,1 & 44,2 & 48,5 & 58,3 \\
\hline Aggression is suppressed & 49,1 & 53,2 & 50,5 & 39,3 \\
\hline
\end{tabular}

Table 4

Distribution of students depending on a type of their character accentuation (\%)

\begin{tabular}{|l|c|c|c|c|}
\hline \multirow{2}{*}{ Accentuation type } & \multicolumn{4}{|c|}{ Classes } \\
\cline { 2 - 5 } & 6 & 7 & 8 & 9 \\
\hline Not diagnosed & 15,5 & 25,0 & 15,5 & 10,7 \\
\hline Instable & 2,7 & - & 1,9 & 5,3 \\
\hline Asthenoneurotic & 1,8 & - & 1,0 & 1,3 \\
\hline Excitable & 7,3 & 2,0 & 4,9 & 1,3 \\
\hline Hyperthymic & 10,9 & 2,0 & 2,9 & 12,0 \\
\hline Demonstrative & 6,4 & 25,0 & 19,4 & 18,7 \\
\hline Introvert & 3,6 & - & 5,8 & 6,7 \\
\hline Unsteady & 1,8 & - & 7,8 & - \\
\hline Sensitive & 2,7 & 2,0 & 4,9 & - \\
\hline Anxious-pedantic & 9,1 & 12,0 & 1,9 & 4,0 \\
\hline Cycloid & 1,8 & 3,0 & 6,8 & 1,3 \\
\hline Mixed & 36,4 & 30,0 & 27,2 & 38,7 \\
\hline
\end{tabular}

Our next examination stage included assessment of life quality and we performed it in order to obtain students' subjective estimations of their health.

We detected the highest score (66 scores) for a physical component of health in the 6th grade where students gave a lot of scores to such parameters as "physical 
functioning" and "role physical functioning"; the lowest score was detected in the 7 th grade, where very few scores were given by students to "physical functioning" and "overall health".

The highest scores for a mental component of health (76 scores) were detected in the 6th grade due to "role emotional functioning" and "social functioning"; the lowest scores were detected in the 8th and 9 th grade (45 scores) due to "role emotional functioning" and "life activity" in the 8th grade, and "life activity" and "mental health" in the 9th grade.

We performed a correlation analysis and detected that a number of students from various age groups who had high anxiety level grew depending on their overall educational loads $(r=0.82)$, a period of time they spent doing their homework $(r=0.92)$, and a period of time they spent outdoors $(r=-0.83)$. Basic life quality parameters changed depending on edu- cational loads during a working day and a week, and it was proved by a detected direct correlation between educational loads and role physical functioning $(r=0.91)$, overall health $(\mathrm{r}=0.91)$, social functioning $(\mathrm{r}=0.98)$, and role emotional functioning $(r=0.91)$.

So, to sum up, we can conclude, that intra-school environment and organization of educational processes in establishments with round-the-clock staying for students cause risks of negative effects on their neuro-psychic state and overall life quality. Therefore, it is necessary to develop and implement up-to-date preventive and health-preserving activities and practicable programs of medical support for children attending such establishments.

Funding. Our research was not granted any sponsors' support.

A conflict of interests. The authors state there is no conflict of interests

\section{References}

1. Akhmadullina Kh.M., Akhmadullin U.Z., Timoshenko K.T., Yalaeva E.T. Vliyanie vnutrishkol'noi sredy na zdorov'e uchashchikhsya $\mathrm{v}$ svete reformirovaniya sistemy obrazovaniya [Effect of Intra-School Environment on the Health of Schoolchildren in the Light of Education Reform]. Vestnik VEGU, 2015, vol. 2, no. 76, pp. 233-242 (in Russian).

2. Baranov A.A., Namazova-Baranova L.S., Al'bitskii V.Yu., Terletskaya R.N., Antonova E.V. Sostoyanie i problemy zdorov'ya podrostkov v Rossii [The condition and problems of adolescents" health of Russia]. Problemy sotsial'noi gigieny, zdravookhraneniya i istorii meditsiny, 2014, no. 6, pp. 10-14 (in Russian).

3. Ashvits I.V., Shirinskii V.A. Gigienicheskaya otsenka zdorov'ya vospitannikov kadetskogo korpusa [Hygienic Health State Evaluation In Alumni Of Omsk Military School]. Vestnik Ural'skoi meditsinskoi akademicheskoi nauki, 2009, vol. 3, no. 26, pp. 6-7 (in Russian).

4. Setko A.G., Terekhova E.A. Fiziologo-gigienicheskaya otsenka izmenenii v sostoyanii zdorov'ya shkol'nikov, obuchayushchikhsya v razlichnykh tipakh obrazovatel'nykh uchrezhdenii [Physiological and hygienic assessment of changes in health of school students attending educational establishments of various types]. Aktual'nye problemy pediatrii: materialy XIX Kongressa pediatrov Rossii s mezhdunarodnym uchastiem, 12-14 fevralya 2016 goda [Vital problems of pediatrics: Materials of the XIX Congress of Russian pediatricians with international participation, February 12-14, 2016]. Moscow, 2016, pp. 270 (in Russian). 
5. Terekhova, E.A. Vliyanie vnutrishkol'noi sredy na funktsional'nye rezervy uchashchikhsya [Influence exerted by intra-school environment on students' functional reserves]. Dni molodezhnoi nauki: materialy $V$ Vserossiiskoi nauchno-prakticheskoi kon-ferentsii s mezhdunarodnym uchastiem, posvyashchennoi 70-letiyu studencheskogo nauchno-go obshchestva im. F.M. Lazarenko Orenburgskogo gosudarstvennogo meditsinskogo universiteta [Days of youth's science: Materials of the V Russian theoretical and practical conference with international participation dedicated to the 70th anniversary of F.M. Lazarenko's Orenburg State Medical University]. Orenburg, 2016, pp. 145-146 (in Russian).

6. Valeeva E.R., Ziyatdinova A.I., Akberova G.R. Gigienicheskaya otsenka vnutrishkol'noi sredy v obrazovatel'nykh uchrezhdeniyakh razlichnogo tipa [Hygienic Assessment Of School Environment In Educational Institutions Of Various Types] Sovremennye problemy nauki $i$ obrazovaniya, 2015, no. 6, pp. 59 (in Russian).

7. Kuchma V.R., Safonkina S.G., Moldvanov V.V. Otsenka svyazi mezhdu zdorov'em detei, poseshchayushchikh obrazovatel'nye uchrezhdeniya, i urovnem ikh sanitarnoepidemiologicheskogo blagopoluchiya [Assessment of relationship between health of children attending educaitonal establishments and their sanitary-epidemiologic state]. Nauchnye vedomosti Belgorodskogo gosudar-stvennogo universiteta. Seriya: Meditsina. Farmatsiya, 2014, vol. 28, no. 24-1 (195), pp. 73-76 (in Russian).

8. Polyakova A.N., Selezneva E.V., Denisova N.B., T.V. Pozdnyakova Sredovye faktory obrazovatel'nogo uchrezhdeniya i sostoyanie zdoro-v'ya uchashchikhsya [The Factors Of School"s Surroundings And Pupil"s Health]. Vestnik novykh meditsinskikh tekhnologii. Elektronnoe izdanie, 2013, no. 1, pp. 242 (in Russian).

9. Setko A.G., Terekhova E.A. Gigienicheskaya otsenka faktorov vnutrishkol'noi sredy i organizatsii uchebno-vospitatel'nogo protsessa na adaptatsionnye rezervy organizma obuchayushchikhsya kadetskogo uchilishcha [Hygienic assessment of influence exerted by intra-school environment factors and educational process organization on adaptation reserves of students attending a round-the-clock military school]. Profilakticheskaya meditsina - 2017: Sbornik nauchnykh trudov Vserossiiskoi nauchno-prakticheskoi konferentsii s mezhdunarodnym uchastiem, 6-7 dekabrya $2017 \mathrm{~g}$ [Prevention medicine - 2017: works collected at the Russian theoretical and practical conference with international participation, December 6-7, 2017]. St. Petersburg, 2017, pp. 41-50 (in Russian).

10. Setko A.G., Mryasova Zh.K., Terekhova E.A. Kompleksnaya otsenka okruzhayushchei sredy kak faktora riska zabolevaemosti detei promyshlennogo goroda [Complex assessment of the environment as a risk factor causing morbidity among children living in an industrial city]. Materialy mezhduna-rodnogo Foruma Nauchnogo soveta $R F$ po ekologii cheloveka i gigiene okruzhayushchei sredy, posvyashchennogo 85-letiyu FGBU «NII ekologii cheloveka i gigieny okruzhayu-shchei sredy im. A.N. Sysina», 15-16 dekabrya $2016 \mathrm{~g}$ [Materials of the International congress held by the RF Scientific Council for human ecology and environmental hygiene, dedicated to the 85-th anniversary of A.N. Syisin's Scientific Research Institute for Human Ecology and Environmental Hygiene, December 15-16, 2016]. Moscow, 2016, pp. 210-213 (in Russian).

11. Terekhova E.A. Osobennosti adaptatsii i rezervnykh vozmozhnostei organizma shkol'nikov [Peculiarities of schoolchildren's body adaptation and reserves]. Innovatsionnye idei molodykh issledovatelei v oblasti biologii, ekologi-cheskoi bezopasnosti i prirodopol'zovaniya: materialy mezhvuzovskoi nauchno-prakticheskoi konferentsii studentov i aspirantov [Innovative ideas of young researchers in the spheres of biology, ecological safety and use of natural re- 
sources: materials of interuniversity theoretical and practical conference for students and postgraduates]. Orenburg, 2015, pp. 73-75 (in Russian).

12. Beilina E.B., Setko N.P., Volodina E.A., Bulycheva E.V. Osobennosti adaptatsionnykh reaktsii organizma shkol'nikov $\mathrm{v}$ usloviyakh obrazova-tel'nogo protsessa [Peculiarities of schoolchildren's adaptation reactions within educational process]. Okhrana zdorov'ya $i$ bezopasnost' zhiznedeyatel'nosti detei i podrostkov. Aktual'nye problemy, taktika i strategiya deistvii: materialy IV Vserossiiskogo kongressa po shkol'noi i universitetskoi meditsine s mezhdunarodnym uchastiem. 2014, pp. 31-32 (in Russian).

13. Setko N.P., Bulycheva E.V., Valova A.Ya. Osobennosti stanovleniya sotsial'nopsikhologicheskoi adaptatsii gimnazistov, obuchayushchikhsya $\mathrm{v}$ sisteme printsipov L.V. Zankova i M. Montessori [Peculiarities of social-psychological adaptation of schoolchildren who are educated within L.V. Zankov and M.Montessori paradigm]. Dushevnoe zdorov'e naseleniya na granitse Evropy i Azii: materialy VI Mezhdunarodnoi konferentsii [Mental health of population living at the Europe-Asia border: materials of the VI International conference]. 2016, pp. 119-120 (in Russian).

14. Novik A.A., Ionova T.I. Rukovodstvo po issledovaniyu kachestva zhizni v meditsine [Guide to the study of quality of life in medicine]. St. Petersburg, Neva Publ., Moscow, OlmaPress Publ., 2002, 315 p. (in Russian).

Setko A.G., Terekhova E.A., Tyurin A.V., Mokeeva M.M. Peculiarities of neuro-psychic state and life quality of children and teenagers formed under influence exerted by risk factors existing in educational environment. Health Risk Analysis, 2018, no. 2, pp. 62-69. DOI: 10.21668/health.risk/2018.2.07.eng

Received: 05.03.2018

Accepted: 01.06.2018

Published: 30.06 .2018 